w Królestwie Polskim wyglosiła mgr Monika Nawrot. Referentka omówiła wymienione zagadnienia w świetle źródeł pamiętnikarskich z XIX i poczatków XX wieku.

Następnie glos zabrali dr Jan Ryś i dr Ryszard Ślęczka, którzy przedstawili referat pt.: Elementarze do nauczania domowego $z$ drugiej polowy XIX wieku. Prof. dr hab. Agnieszka Stopińska-Pająk zwróciła uwagę w swym wystąpieniu na znaczenie kalendarzy w rodzinnym nauczaniu domowym na Górnym Ślassu. Ostatni w tej części obrad referat wygłosiła mgr Agnieszka Szarkowska, która skupiła się na roli wychowania religijnego w nauczaniu domowym dzieci w okresie zaborów.

Drugi dzień obrad, którym przewodniczyła prof. dr hab. Alicja Kicowska, rozpoczął referat prof. dr hab. Romualda Grzybowskiego na temat udziału prasy w nauczaniu domowym dzieci polskich na Pomorzu Nadwiślańskim w drugiej połowie XIX i pierwszych latach XX wieku. Prof. dr hab. Grzegorz Michalski zwrócił uwage na wskazania dla edukacji domowej, jakie można odnaleźć w polskim czasopiśmiennictwie drugiej połowy XIX wieku i w pierwszych latach XX wieku.

Prof. dr hab. Władysława Szulakiewicz postawiła w swym referacie pytanie o istotę i specyfikę zawodu nauczyciela domowego.

Następnie głos zabrała dr Katarzyna Kabacińska, która przedstawiła referat pt.: Nauczyciel domowy - ideat a rzeczywistość.

Tę część obrad zakończyło wystapienie mgr Grażyny Karłowskiej, która przedstawiła, w formie prezentacji multimedialnej, charakterystykę nauczycieli domowych na ziemiach polskich w XIX i na poczatku XX wicku.

Ostatnią część obrad poprowadził prof. dr hab. Karol Poznański. Jako pierwszy w tej części obrad referat wygłosił prof. dr hab. Tadeusz Jałmużna. Referent poświęcil go w całości analizie zagadnienia nauczania domowego w twórczości Henryka Wemica. Z kolei dr Iwonna Michalska zwróciła uwagę na wkład twórczości Teofila Nowosielskiego do edukacji domowej.

Dwa ostatnie referaty przedstawiały zagadnienie nauczania domowego ze stanowiska socjologicznego i współczesnej myśli pedagogicznej. Dr Marek Budajczak zwrócił uwagę na społeczne dawne i współczesne wymiary edukacji domowej, natomiast dr Roman Leppert omówił historyczne i religijne źródła współczesnego nauczania domowego w USA.

Podsumowania konferencji dokonał prof. dr hab. Karol Poznański, który podkreślił wysoki poziom konferencji, zwrócił uwagę na aktualność problematyki nauczania domowego í potrzebę dalszego prowadzenia badań w tym zakresie.

Grazyna Kartowska

\title{
Konferencja „Rozwój pedagogiki jako nauki i kierunku studiów na Słowacji”. Bratysława, 22 - 23 września 2003 r.
}

W dniach 22 - 23 września 2003 roku na Uniwersytecie im. J. A. Komeńskiego w Bratysławie odbyła się konferencja naukowa, której tematyką był Rozwój pedagogiki jako nauki i kierunku studiów na Stowacji.

Konferencja miała charakter międzynarodowy, a wśród jej uczestników znaleźli się naukowcy nie tylko ze Słowacji, ale między innymi z Czech, Polski, Chorwacji.

Organizatorem konferencji była Katedra Pedagogiki Uniwersytetu Komeńskiego w Bratysławie. Otwarcia konferencji dokonała kierownik Katedry Pedagogiki Uniwersytetu Komeńskiego - doc. Z. Baduriková. Przybyłych gości powitał również dziekan Wydziału Filozoficznego Uniwersytetu Komeńskiego w Bratysławie - doc. Anton Eliáš. Wykład inauguracyjny o seminarium pedagogicznym na Uniwersytecie Komeńskiego w kontekście rozwoju myśli pedagogicznej na Słowacji, wygłosił prof. Jozef Pšenák. Następnie głos zabrał prof. Štefan Švec, który mówił o potrzebie pedagoga szkolnego. 
Jako ostatni, w głównej części obrad, referat wygłosił prof. Martin Žilinek. Referent zwrócił uwagę na humanistyczne aspekty wychowania moralnego. Dalsza część obrad odbywała się już w wyznaczonych tematycznie sekcjach.

W ciagu dwóch dni konferencji wysłuchano 55 referatów. Obrady toczyły się w trzech sekcjach.

W sekcji pierwszej dyskusje toczyły się wokół kierunków rozwoju subdyscyplin pedagogicznych $i$ ich roli w przygotowaniu nauczycieli. Wystapienia referentów sekcji drugiej dotyczyły pedagogiki jako nauki, kierunku studiów i pracy. Obrady sekcji trzeciej prowadzone były pod hasłem współpracy Katedry Pedagogiki Uniwersytetu Komeńskiego ze słowiańskimi i zagranicznymi ośrodkami naukowymi.

Obrady sekcji pierwszej rozpoczął referat B. Kasáčovej nt. teoretycznego i praktycznego stanowiska nowoczesnej pedeutologii. Kolejny referat $\mathrm{H}$. Kasikovej poświęcony był działalności i funkcjonowaniu Studium Nauczycielskiego na Wydziale Filozoficznym UK w Pradze. J. Krstovic i R. Čepič przedstawili z pozycji doświadczeń chorwackich kierunki rozwoju w kształceniu zawodowym nauczycieli w kontekście uczenia się przez całe życie.

Referat na temat podstaw pedagogiki ogólnej i jej roli w systemie przygotowania przyszlych nauczycieli wygłosili V. Kurincova i P. Seidler. Kolejny referent J. Danek omówił znaczenie dyscyplin pedagogicznych w studiach nauczycieli przedmiotów ogólnokształcących. M. Polaček zwrócił uwagę na dyscypliny psychologiczne w przygotowaniu przyszłych nauczycieli. Z kolei V. Ŝvec i M. Sadilova skupili siẹ na integracji dyscyplin psychologicznych $i$ pedagogicznych $w$ przygotowaniu nauczycieli. Kolejny referent $V$. Kováčová podjęła $w$ swym referacie problem celowości treści pedagogiki ogólnej w przygotowaniu nauczycieli. Na temat trendów w rozwoju historii szkolnictwa $\mathrm{i}$ pedagogiki $\mathrm{i}$ ich roli $\mathrm{w}$ przygotowaniu nauczycieli mówiła V. Žbirková. W dalszej kolejności referat wygłosiła J. Ivančikova, która omówiła znaczenie studiowania dydaktyki dyferencyjnej $w$ procesie przygotowania przyszłych nauczycieli A. Douškova i Ŝ. Porubský zwrócili uwagę na pojęcie dydaktyki elementarnej w kontekście zawodu nauczyciela (w odniesieniu do nauczyciela szkoły podstawowej). Sytuację rozwoju dyscyplin pedagogicznych $w$ przygotowaniu nauczycieli na Wydziale Pedagogicznym Uniwersytetu w Trnavie opisywał referat M. Śpánik. Z kolei V. Cabanova przedstawiła profil absolwentów studiów nauczycielskich na Uniwersytecie Katolickim w Ruomberku. Na temat roli dyscyplin pedagogicznych $w$ przygotowaniu nauczycieli wychowania przedszkolnego mówili: N. Babic i S. Irovič. Natomiast referat o znaczeniu pedagogiki $w$ przygotowaniu nauczycieli wychowania fizycznego i sportu wygłosili: M. Kips i A. Pavlikova.

Zagadnienie andragogiki w kontekście edukacji seniorów omówiła B. Balogova. Referat na temat kształcenia pracowników miejskiej regionalnej kultury wygłosił S. Chomova. Jako kolejna głos zabrała E. Kratochvilova, która przedstawiła pedagogikę wolnego czasu w zestawieniu z naukami pedagogicznymi. Z. Bokašova omówiła pedagogikę socjalną jako część studiów pedagogicznych. Referat na temat integracji dyscyplin pedagogiczno-psychologicznych w przygotowaniu pedagoga socjalnego wygłosiła M. Sadilova. Jako następna referat na temat wzajemnych stosunków i powiazań pedagogiki i pedagogiki specjalnej przedstawiła A. Vanc̄ova.

Zagadnienie pedagogiki zdrowotnej poruszyła w swym wystapieniu M. Horňkova. I. Pavlov próbował w swym referacie dać odpowiedź na pytanie czy metodyk szkolny to funkcja która może zrobić karierę?

Doświadczeniami inspekcji szkolnej z kontroli w szkole państwowej podzieliła się G. Vanekova. Jako ostatnia w obradach sekcji pierwszej głos zabrała M. Matulčikova, która przedstawiła kierunki reform $w$ rozwoju szkolnictwa i płynące $z$ nich wyzwania dla rozwoju pedagogiki.

W ramach obrad drugiej sekcji swoje referaty przedstawiło 25 osób.

Obrady rozpoczałł referat A. Vukasovica pt.: Rozwój pedagogiki jako kierunku studiów i dyscypliny naukowej w Chorwacji. W dalszej kolejności referat wygłosiła - B. Kudlačová, która przedstawiła znaczenie antropologii dla pedagogiki. Następnie głos zabrała V. Dubravova, która zaprezentowała pogląd filozofów na paradygmaty w dziedzinie nauki o wychowaniu na Słowacji. 
Zagadnienie pedagogiki jako kierunku studiów, przedmiotu nauki i pracy poruszyła w swym wystapieniu V. S̃vecova. Kolejna referentka G. Porubska zwróciła uwagę na położenie dydaktyki w systemie nauk pedagogicznych. Natomiast B. Kosova wygłosiła referat pt.: Teoria wychowania a teoria rozwoju indywidualności.

Kolejna referentka - M. Dvỡáková zwróciła uwagę na pedagogikę jako kierunek studiów na FF (Fakultecie Filozoficznym) Uniwersytetu w Pradze. O tradycjach i współczesności przedmiotu pedagogika na FF Uniwersytetu w Prešovicach mówiła M. Černotová.

W dalszej kolejności głos zabrała E. Turanska, która omówiła położenie i rolę dziejów pedagogiki na „pedagogice” jako kierunku studiów. Z kolei D. Kovačikova przedstawiła położenie i rolę pedagogiki porównawczej na pedagogicznym kierunku studiów.

Referat na temat rozwijania myślenia uczniów w procesie wczesnoszkolnej edukacji zintegrowanej przedstawił M. Lelonek. Kolejni referenci: B. Pupala i Z. Kollarikova omówili w swym referacie położenie pedagogiki elementarnej na Słowacji.

Zagadnienie pedagogiki medialnej w krajach niemieckojęzycznych omówiła V. Kaćinová. Natomiast J. Levicka odniosła się w swym referacie do niektórych pytań stawianych w ramach pedagogiki jako kierunku kształcenia akademickiego.

Następna referentka - A. Tokarova, podjęła próbę przedstawienia wzajemnych relacji, jakie zachodza między andragogika a praca socjalna.

M. Gnoth natomiast skupił się w swym referacie na znaczeniu i roli dyscyplin pedagogicznych w przygotowaniu nauczycieli na Wydziale Przyrodniczym Uniwersytetu Komeńskiego. Z kolei E. Fulkova zwrócila uwagę na przygotowanie pedagogiczne nauczycieli przedmiotów zawodowych w rolniczych szkołach średnich. Natomiast o przygotowaniu nauczycieli przedmiotów rolniczych na przykładzie Uniwersytetu Rolniczego w Nitrze na Słowacji, mówił M. Michalek. J. Vašutova zwróciła uwagę słuchaczy na rolę pedagogiki jako przedmiotu akademickiego, kształcacego przyszłych nauczycieli.

Doświadczenia z organizacji praktyk pedagogicznych, ich przebiegu i realizacji na Wydziale Filozoficznym Uniwersytetu w Pres̃owie, omawiał referat M. Goga.

Jako następna głos zabrała S. Kompoltowa, która zwróciła uwagę na położenie pedagogiki, jako przedmiotu kształcenia w programie nauczania nauczycieli przedmiotów ekonomicznych. Z kolei R. Şlosár zwrócił uwagę na znaczenie dydaktyki w przygotowaniu nauczycieli przedmiotów ekonomicznych.

Jako ostatnia w obradach sekcji drugiej głos zabrała M. Zahatňanska, która zwróciła uwagę na wykorzystanie metody heurystycznej w przygotowaniu studentów.

W obradach sekcji trzeciej głos zabrało 9 referentów. J. Zounek omówił wpływ O. Chlupa na działalność Uniwersytetu Masaryka w Brnie i Uniwersytetu Komeńskiego w Bratysławie. R. Vaňova przedstawiła praski okres działalności naukowej Josefa Hendricha. Następny referent J. Uhlirova omówiła wkład Jana Uhra w podwyższenie poziomu kształcenia nauczycieli słowackich. Natomiast J. Pšenák podkreślił wpływ J. Čečetku na rozwój Wydziału Filozoficznego UK w Bratysławie.

Następny referent V. Michalička odniósł się do niektórych stron dzieła Jozefa Máteja.

Referat o historii wychowania jako subdyscyplinie nauk pedagogicznych, a także przedmiocie kształcenia akademickiego w Polsce, wygłosili W. Jamrożek i K. Jakubiak. Kwestia wspólpracy pedagogów preszowskich z Katedrą Pedagogiki Wydziału Filozoficznego UK podjęta została w wystapieniu I. Kominarec. Wkład Katedry Pedagogiki FF PU w rozwój pedagogiki i szkolnictwa na Słowacji przedstawił E. Lukáč. Jako ostatnia w obradach sekcji głos zabrała M. Potočárová, która przedstawiła projekt badawczy powstały we wspólpracy z Uniwersytetem w Groningen. Projekt skupia się na zagadnieniu wpływu rodziny na kształtowanie postaw młodzieży.

Obrady w poszczególnych sekcjach zakończyło wspólne spotkanie referentów, na którym dokonano podsumowania dwudniowych obrad $\mathrm{i}$ wysunięto płynące $\mathrm{z}$ nich wnioski.

Grazyna Karlowska 